\title{
Growth Delay after Liver Transplantation in Childhood: Studies of Underlying Mechanisms
}

\author{
SAMU SARNA, ILKKA SIPILÄ, ELINA VIHERVUORI, RIITTA KOISTINEN, AND \\ CHRISTER HOLMBERG \\ Children's Hospital [S.S., I.S., E.V., C.H.] and the Department of Obstetrics and Gynecology [R.K.], \\ University of Helsinki, Helsinki, Finland
}

\begin{abstract}
After liver transplantation in children, growth is often impaired, but the underlying mechanisms are unknown. Glucocorticoids used for immunosuppression are believed to be partly responsible. After renal transplantation in children, reduced growth hormone $(\mathrm{GH})$ secretion and increased serum insulin-like growth factor-binding protein-3 (IGFBP-3) levels have been reported. We attempted to find endocrine factors predicting growth in 18 prepubertal children followed for more than $1 \mathrm{y}$ (mean 2.4 y) after liver transplantation. Spontaneous and stimulated GH secretion, serum IGF-l, IGFBP-3 concentrations, and

correlated positively with serum basal $\left(r_{\mathrm{s}}=0.44, p<0.05\right)$ and stimulated $\left(r_{\mathrm{s}}=0.53, p<0.005\right)$ cortisol concentration. In conclusion, after liver transplantation 1) the normal pulsatile character of nocturnal $\mathrm{GH}$ secretion is sustained, and the $\mathrm{GH}$ response to stimulation is reduced in only a few patients; 2) serum IGF-I concentrations are normal; 3) serum IGFBP-3 concentrations are elevated or in the upper part of the normal range in most patients; and 4) endogenous cortisol production is reduced in most patients and correlates positively with growth velocity. (Pediatr Res 38: 366-372, 1995)
\end{abstract} endogenous cortisol production were measured. GH secretion was reduced in only two patients. Serum IGF-I concentration was normal, but serum IGFBP-3 was elevated or $1 \mathrm{SD}$ above the mean for age in $62 \%$ of the patients. Endogenous cortisol production was reduced in most patients during the first year and improved later in only a few. Growth velocity after transplantation did not correlate with GH secretion, serum IGF-I or IGFBP-3 concentration, or with methylprednisolone dose, but

Chronic liver disease in childhood often results in growth retardation $(1,2)$. This is believed to be mainly due to nutritional impairment (3), and alterations in the production or action of GH and/or IGF-I (4). Previously, prevention of growth retardation was not a primary aim in these patients, as their survival time was relatively short. However, during the last decade, liver $\mathrm{Tx}$ has offered long-term survival for these children. With improvement of diagnostic methods, surgical technique, immunosuppression, and treatment of complications, 4-y patient survival rates of 77 and $67 \%$ have been reported for children over and under $1 \mathrm{y}$ of age, respectively (5).

After a successful liver Tx, the long-term effects of chronic liver disease, for example malnutrition, gradually regress. Yet $15-59 \%$ of the patients remain or drop outside of the normal range for height $(6,7)$. The mechanisms underlying this growth

Reccived October 27, 1994; accepted March 28, 1995

Correspondence and reprini requests: Samu Sarna, Chiloren's Hospital, University of Helsinki, Stenbäckinkatu 11, SF-00290, Helsinki, Finland.

Supported by the Sigfrid Jusćlius Foundation.

\author{
AZA, azathioprine \\ CyA, cyclosporine A \\ IGFBP-3, insulin-like growth factor-binding protein-3 \\ MP, methylprednisolonc \\ Tx, transplantation
}

Abbreviations

retardation are unknown, although glucocorticoid-mediated inhibition of GH secretion may be at least partly responsible (8). Abnormalities of thyroid function or calcium and phosphate metabolism after liver $\mathrm{Tx}$ in childhood have not been found (9). Height at $\mathrm{Tx}$ has been found to correlate negatively with growth after Tx, which shows that the more growth is retarded, the greater is the potential for catch-up once the child obtains a well functioning liver (9). The weight-for-height index at the time of 'Tx may serve as an indicator of the patient's nutritional status and correlates positively with subsequent growth (9). However, both height and weight-for-height at $\mathrm{Tx}$ seem to predict growth mainly during the first year after Tx (9). The main factors inhibiting long-term growth of these children may be poor graft function and/or glucocorticoid-mediated changes in the GH-IGF-I axis and growth plate metabolism $(9,10)$.

Growth is also often inhibited after renal Tx, and among the factors responsible may be reduced $\mathrm{GH}$ secretion with increased levels of serum IGFBP-3 (11). To investigate whether similar abnormalities are present and responsible for the growth inhibition in children with liver transplants, we studied the relations of $\mathrm{GH}$ secretion, IGF-I and IGFBP-3 serum 
concentrations, immunosuppressive medication, and endogenous cortisol production to growth in 18 prepubertal children followed for more than 1 y after liver Tx.

\section{METHODS}

Subjects. Between October 1987 and August 1993, 37 liver Txs were performed on 31 children at the Children's Hospital, University of Helsinki, Helsinki, Finland. First-year patient survival was $79.3 \%$, and graft survival was $60.7 \%$. Only prepubertal patients followed for more than $1 \mathrm{y}$ after Tx are reported in the present study ( $n=18,11$ boys and 7 girls). Twelve of these received a reduced size liver and two patients an ABO-incompatible graft. Mean age at Tx was 3.1 y (range 0.4 to $10.8 \mathrm{y})$. The indications for Tx were: hereditary tyrosinemia $(n=8)$, biliary atresia $(n=5)$, hepatoblastoma $(n=3)$, cirrhosis $(n=1)$, and $\alpha_{1}$-antitrypsin deficiency $(n=1)$. Mean follow-up time was 29 mo (range 12 to $60 \mathrm{mo}$ ).

Immunosuppression. CyA, $5 \mathrm{mg} / \mathrm{kg}$ p.o., was given preoperatively. MP, $100 \mathrm{mg}$ i.v., and AZA, $1.4 \mathrm{mg} / \mathrm{kg}$ i.v. in two doses, were given intraoperatively. Postoperative immunosuppression included MP, $3 \mathrm{mg} / \mathrm{kg} / \mathrm{d}$ p.o., which was tapered down to $0.25 \mathrm{mg} / \mathrm{kg}$ at $1 \mathrm{mo}$, and to $0.37 \mathrm{mg} / \mathrm{kg}$ every other day after 6 mo if the clinical condition was stable. Eighteen and 36 mo after the $\mathrm{Tx}, 88 \%$ of the patients were on alternate-day steroids; AZA, $2 \mathrm{mg} / \mathrm{kg} / \mathrm{d}$ p.o., which was reduced to $1 \mathrm{mg} / \mathrm{kg} / \mathrm{d}$ after 2 wk and increased to $1.4 \mathrm{mg} / \mathrm{kg} / \mathrm{d}$ at 6 mo when the MP dose was reduced; CyA, given as a continuous i.v. infusion for the first $2 \mathrm{wk}$, aiming at a blood trough concentration of $500 \mu \mathrm{g} / \mathrm{L}$ (specific monoclonal RIA, Sandimmun Kit, Sandoz, Basel, Switzerland). After $2 \mathrm{wk}$, the patients were switched to peroral CyA three times a day, aiming at a blood trough concentration of 300 to $500 \mu \mathrm{g} / \mathrm{L}$. The dose was slowly reduced to maintain a concentration between 100 and $200 \mu \mathrm{g} / \mathrm{L}$ after $1 \mathrm{y}$. In the first nine patients, AZA was given only for the first 2-6 mo after Tx. In 1991, we started triple immunosuppression, and AZA has been added to the medication of most of the older patients. The doses of the immunosuppressive medication are expressed as $\mathrm{mg} / \mathrm{kg}$, to be comparable with those reported in most previous studies $(6,7)$.

Complications. Acute rejection episodes were documented in 16 of the 18 patients studied. Ten patients had one, five patients two, and one patient three rejection episodes. Most rejections occurred during the first postoperative month except in three patients who underwent two rejection episodes, one shortly after Tx, and the second 3, 6, or 18 mo after Tx. All rejections were treated with MP $1.5 \mathrm{mg} / \mathrm{kg}$ p.o., followed by 3 $\mathrm{mg} / \mathrm{kg} / \mathrm{d}$ p.o. for $5 \mathrm{~d}$. The dose was then tapered back down in $1 \mathrm{wk}$.

Major complications in the 18 patients studied were: 1) vanishing bile duct syndrome in three patients (all have been retransplanted, one died postoperatively in sepsis); 2) Burkitt's lymphoma after Epstein-Barr virus infection in one patient (responded to one cycle of cytostatic treatment and radiotherapy after AZA and CyA had been stopped); 3) occlusion of the hepatic artery 8 mo after Tx, and a liver abscess after 18 mo (Aspergillus flavus; responded to liposomal amphotericin B and peroral itraconazole) in one patient; and 4) familial pol- yposis of the colon in one patient (panproctocolectomy and ileostomy performed 20 mo after Tx).

Follow-up visits. After Tx, all of the 18 patients studied were seen regularly at the local hospital and at our outpatient clinic every 3 mo for the first year, and subsequently every 6 mo. The following laboratory data were obtained: total blood count and thromboplastin time, lidocaine test (12), GFR $\left({ }^{51} \mathrm{Cr}-\right.$ EDTA-clearance), blood specific CyA, serum alanine aminotransferase, $\gamma$-glutamyl transferase, albumin, prealbumin, total and conjugated bilirubin, creatinine, and urea nitrogen concentration. The laboratory analyses were performed by routine methods.

Auxologic measurements. Height and weight determinations were performed at noon by the same trained observers using a Harpenden stadiometer (Holtain LTD., Crymych, Dyfed, UK) for height measurements. Bone age determinations, performed in 13 patients, were done by the same observer according to the Tanner-Whitehouse 2 (20 bones) method (13).

Nocturnal GH secretion. Measurement of nocturnal 8-h GH secretion was added to our follow-up protocol in 1990 and performed 12 mo after Tx. In addition, nocturnal GH secretion was measured in some of the older patients already followed for more than $12 \mathrm{mo}$. Thus, the measurements were performed in 11 patients $12 \mathrm{mo}$, in three patients $24 \mathrm{mo}$, and in one patient 36 mo after Tx. Blood samples were collected from 2200 to $0600 \mathrm{~h}$ at 20 -min intervals. Serum GH concentration was measured by monoclonal immunoradiometric assay, using a commercially available kit (C.I.S., Gif-sur-Yvette, Cedex, France). The GH results of our MAb assay were compared with other GH assays, and a strong correlation ( $r=0.996)$ was found with the results of the polyclonal antibody assay supplied by Pharmacia, Uppsala, Sweden.

GH measurements were analyzed using a personal computer version of the Pulsar peak analysis program with the settings G1 3.98, G2 2.4, G3 1.680, G4 1.240, and G5 0.93 times our interassay SD as criteria for accepting peaks (14). Obtaining control data from healthy children was considered unethical, and the results were compared with control data of the 8-h overnight GH secretion from the literature (8).

Stimulation tests. Serum GH concentrations after stimulation were measured in 11 patients at $6 \mathrm{mo}$, in 12 at $12 \mathrm{mo}$, in six at $24 \mathrm{mo}$, and in four at $36 \mathrm{mo}$ after Tx. GH secretion was stimulated using peroral clonidine and/or insulin-induced hypoglycemia followed by arginine infusion.

The clonidine test (mainly used at the time) was performed on seven patients 6 mo after Tx, using peroral clonidine 75 $\mu \mathrm{g} / \mathrm{m}^{2}$ (Catapresan, Bochringer Mannheim, Germany). Blood samples were collected at 30-min intervals for $2 \mathrm{~h}$.

The insulin-arginine test performed in the other patients was followed by a rapid ACTH test to evaluate the endogenous cortisol production induced by hypoglycemia and ACTH. The test was performed in the morning before the medication was taken. Each patient had fasted $10 \mathrm{~h}$ before the test. The test was started before $0900 \mathrm{~h}$ when a basal blood sample was collected for serum cortisol and $\mathrm{GH}$ measurements. Cortisol was measured using a commercial RIA kit (Farmos Diagnostica, Turku, Finland). After the basal $\mathrm{GH}$ and cortisol samples, $4 \mathrm{IU} / \mathrm{m}^{2}$ i.v. of insulin was injected and the blood glucose concentration 
was measured after $20 \mathrm{~min}$. Hypoglycemia was defined as a blood glucose concentration $<2 \mathrm{mmol} / \mathrm{L}$. Blood samples were collected $30,60,90$, and $120 \mathrm{~min}$ after the insulin injection for cortisol and GH measurements. Samples for serum cortisol measurements were collected additionally 180 and $240 \mathrm{~min}$ after the insulin. L-Arginine $5 \mathrm{~g}$ i.v. was infused after the 60 -min sample and $0.25 \mathrm{mg} / 1.73 \mathrm{~m}^{2}$ i.v. of synthetic ACTH (S-Cortrophin, Organon, Oss, Netherlands) was injected after the 120 -min sample. We have previously shown that the results of an ACTH test after insulin-arginine administration are valid (15). In a few patients, stimulated cortisol secretion was evaluated only by the rapid ACTH test.

GH secretion was considered subnormal when the highest serum GH concentration after stimulation was $<10 \mu \mathrm{g} / \mathrm{L}$ in two stimulation tests. Cortisol secretion was considered subnormal when the basal serum cortisol concentration was $<200$ $\mathrm{nmol} / \mathrm{L}$, and the highest concentration after stimulation $<400$ $\mathrm{nmol} / \mathrm{L}$, or less than twice the basal concentration.

IGF-I and IGFBP-3 measurements. All measurements were performed in the morning after an overnight fast. IGF-I was measured in 14 patients at 12 , in six at 24 , and in nine at 36 mo after Tx using RIA (ImmunoNuclear Corp., Stillwater, $\mathrm{MN})$. In this assay serum samples were incubated in a buffer containing heparin, known to release IGF-I from its binding proteins and prevent reassociation of the complexes (16).

IGFBP-3 measurements were performed in five patients 12 $\mathrm{mo}$, in five $24 \mathrm{mo}$, and in six $36 \mathrm{mo}$ after Tx. In the IGFBP-3 immunofluorometric assay (17), MAb F42-1B6 was bound to microtiter wells, and the second antibody F41-5C11 was labeled with europium chelate. Neither assay cross-reacts with other IGFBPs or IGFs. Control values of serum IGFBP-3 have been determined previously (16), and in this study the serum IGF-I control values were measured from the same samples ( $n$ $=135$ for IGF-I and $n=139$ for IGFBP-3). The IGF-I and IGFBP-3 data are age-adjusted, as all patients were prepubertal, and there were no sex differences in this age group.

Data analyses. Height SD score (hSDS) was calculated according to the following equation: $\mathrm{hSDS}=$ (observed value - mean value)/SD (SD represents the $\mathrm{SD}$ for the normal population of the same chronologic age and gender) (18). Growth velocity was defined as the annual change in hSDS ( $\triangle$ SDS). Growth velocity was correlated with various laboratory measurements, and $\triangle$ SDS was calculated from height measurements performed 6 mo before and after each measurement. The weight-for-height index, expressed as a percentage, was determined from the ratio of weight $(\mathrm{kg})$ to height $(\mathrm{cm})$, and the ratio of the 50 th percentile weight for age to the 50 th percentile height for age (19).

For more exact determination of the MP dosage of each patient a weighted average was calculated as follows. Average MP dose between follow-up visits $=\Sigma$ (duration of the dose $(\mathrm{d})$ $X$ dose for weight)/time between follow-up visits (days). The average weight $(\mathrm{kg})$ for each period was calculated from the weight measurements at the follow-up visits.

The associations between the different variables was tested using the Spearman rank-order correlation coefficient $\left(r_{\mathrm{s}}\right)$. Because of the nature of our follow-up protocol, the various measurements were performed at different times after Tx.
Thus, the effect of time as a confounding variable was tested using the Kendall partial rank-order correlation coefficient $(\tau)$ and is reported if a significant effect was found. Correlations were considered significant with the $p$ value $<0.05$.

\section{RESULTS}

Growth. Growth before and after liver Tx is presented in Figure 1 and with the demographic data in Table 1. Median height at $\mathrm{Tx}$ was $-1.3 \mathrm{SD}$. Median $\triangle \mathrm{SDS}$ was $-0.77 \mathrm{SD}$ during the first, $-0.12 \mathrm{SD}$ during the second, and $0.18 \mathrm{SD}$ during the third year after Tx. Three years after Tx, 6/8 children were $<2$ SDs for height (at $\mathrm{Tx} 4 / 8$ of these children were already $<2 \mathrm{SD}$ for height). In the patients without major complications, growth velocity was reduced in $83 \%$ during the first, in $31 \%$ during the second, and in $25 \%$ during the third year after Tx. Growth velocity correlated positively $\left(r_{\mathrm{s}}=0.46\right.$, $p<0.001)$ with time elapsed after Tx.

The nutritional status of all patients was good and weightfor-height remained normal in all but three patients (patients 9 , 12 , and 17), whose weights increased above the normal range 12,36 , and 24 mo after Tx, respectively. In $62 \%$ of the patients bone age was delayed by more than $1 \mathrm{y}$ in relation to chronologic age.

$\boldsymbol{G H}, \boldsymbol{I G F}-\boldsymbol{I}$, and $\mathbf{I G F B P}-3$. The normal pulsatile character of nocturnal $\mathrm{GH}$ secretion was sustained in all patients studied. Table 2 gives various parameters of the Pulsar analysis. Only two patients had a mean $\mathrm{GH}$ concentration below $3.0 \mu \mathrm{g} / \mathrm{L}$, and in one of them the $\mathrm{GH}$ response to stimulation was also reduced (patient 9). The $\mathrm{GH}$ response was subnormal in 2 of 17 patients after Tx. However, both patients were growing normally at the time of the measurements. Neither the parameters of the Pulsar analysis nor the peak GH response to stimulation correlated significantly with growth velocity.

None of the patients had a low serum IGF-I concentration after Tx. The median IGF-I concentration was $-0.3 \mathrm{SD}$ at 12 mo, 0.2 SD at $24 \mathrm{mo}$, and $0.2 \mathrm{SD}$ at $36 \mathrm{mo}$ after Tx. Serum IGF-I concentration did not correlate significantly with growth velocity.

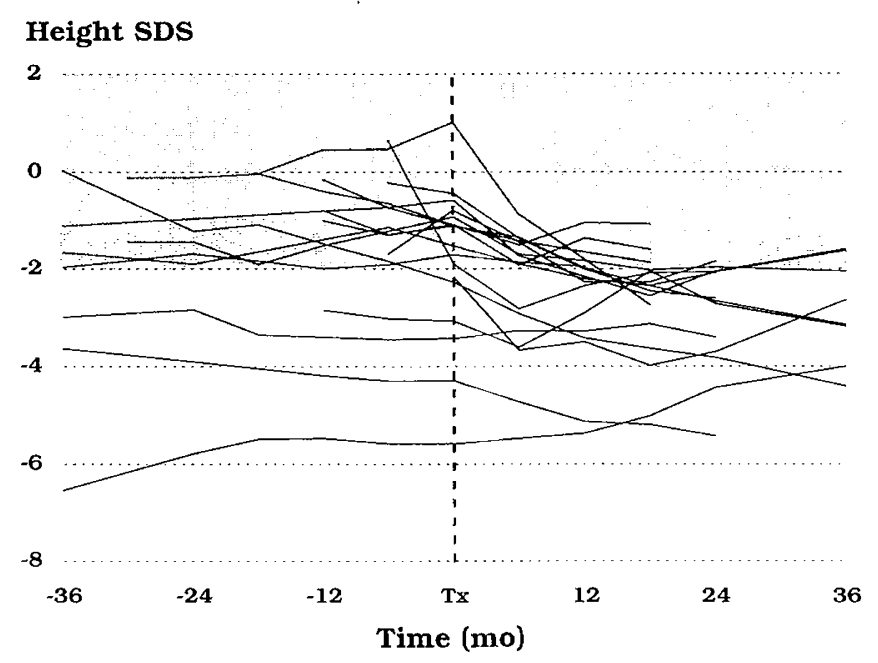

Figure 1. Growth in 18 prepubertal children 36 mo before and after liver Tx. Height is expressed as SD scores (SDS). 
Table 1. Demographic data and growth before and after liver Tx in 18 prepubertal children

\begin{tabular}{|c|c|c|c|c|c|c|c|}
\hline \multirow{3}{*}{$\begin{array}{c}\text { Patient } \\
\text { no. }\end{array}$} & \multirow[b]{3}{*}{ Sex } & \multirow[b]{3}{*}{ Diagnosis } & \multirow{3}{*}{$\begin{array}{c}\text { Age at Tx } \\
(y)\end{array}$} & \multicolumn{4}{|c|}{ Annual growth velocity $(\mathrm{cm} / \Delta \mathrm{hSDS})$} \\
\hline & & & & \multirow[b]{2}{*}{ Before Tx } & \multicolumn{3}{|c|}{ After $T x$} \\
\hline & & & & & 1 st y & 2nd $y$ & $3 r d y$ \\
\hline 1 & $M$ & Tyrosinemia & 0.4 & & $13.9 /-1.32$ & $9.4 /-0.20$ & $5.7 / 0.95$ \\
\hline 2 & $\mathrm{~F}$ & Biliary atresia & 0.7 & & $9.4 /-0.46$ & $7.6 / 0.29$ & $7.0 / 0.44$ \\
\hline 3 & M & Tyrosinemia & 0.9 & & $8.6 /-1.48$ & $7.6 / 0.4 \cdot 3$ & \\
\hline 4 & $\mathrm{M}$ & Tyrosinemia & 1.1 & $20.8 /-0.42$ & $5.7 /-1.62$ & $6.9 / 0.12$ & $8.1 / 0.45$ \\
\hline 5 & M & Tyrosinemia & 1.1 & $22.4 /-0.32$ & $7.5 /-0.87$ & $6.1 /-0.09$ & \\
\hline 6 & M & Tyrosinemia & 1.4 & $14.9 /-0.08$ & $7.0 /-0.29$ & & \\
\hline $7 \dagger$ & $\mathrm{M}$ & Biliary atresia & 1.5 & $11.2 /-0.22$ & $8.1 / 0.16$ & $7.0 / 0.19$ & $4.0 /-0.46$ \\
\hline $8 *$ & $\mathrm{~F}$ & Tyrosinemia & 1.8 & $17.5 /-0.22$ & $0.9 /-1.57$ & $4.2 /-0.60$ & \\
\hline 9 & $\mathrm{~F}$ & Biliary atresia & 2.0 & $8.8 /-0.70$ & $8.0 / 0.00$ & & \\
\hline 10 & $\mathrm{~F}$ & Tyrosinemia & 2.3 & $11.4 / 0.60$ & $4.2 /-0.91$ & $5.7 /-0.13$ & $5.6 /-0.08$ \\
\hline $11^{*}$ & $\mathrm{M}$ & Tyrosinemia & 2.7 & $10.8 / 0.55$ & $0.3 /-2.82$ & & \\
\hline $12 * *$ & $\mathrm{~F}$ & Hepatoblastoma & 3.2 & $4.5 /-0.79$ & $1.4 /-1.14$ & $3.5 /-0.40$ & $2.0 /-0.59$ \\
\hline $13+\dagger$ & M & Hepatoblastoma & 4.4 & $5.5 /-0.10$ & $1.8 /-0.84$ & $3.6 /-0.30$ & \\
\hline 14 & $\mathrm{M}$ & Biliary atresia & 4.9 & $4.9 / 0.00$ & $5.5 / 0.21$ & $8.8 / 0.93$ & $6.4 / 0.43$ \\
\hline $15 *$ & M & Biliary atresia & 5.4 & $6.0 /-0.02$ & $5.6 / 0.14$ & $3.8 /-0.12$ & \\
\hline 16 & $\mathrm{~F}$ & Hepatic cirrhosis & 5.6 & $7.1 / 0.28$ & $4.0 /-0.25$ & & \\
\hline 17 & $\mathrm{~F}$ & $\alpha_{\lrcorner}$-antitrypsin deficiency & 5.9 & $5.3 /-0.13$ & $2.1 /-0.69$ & $2.8 /-0.44$ & $1.5 /-0.49$ \\
\hline 18 & $\mathrm{M}$ & Hepatoblastoma & 10.8 & $2.8 /-0.30$ & $0.0 /-0.55$ & & \\
\hline
\end{tabular}

Major complications.

* Vanishing bile duct syndrome (patient 8, $25 \mathrm{mo}$, patient 11, $22 \mathrm{mo}$, and patient 15, 27 mo after Tx).

** Hepatic artery thrombosis ( 8 mo after Tx), aspergillosis ( 18 mo after Tx).

† Burkitt's lymphoma (18 mo after Tx).

†† Familial polyposis of the colon (panproctocolectomy and ileostomy performed 20 mo after Tx).

Table 2. Parameters of overnight GH secretion in 11 children one year after liver transplantation

\begin{tabular}{ccccc}
\hline $\begin{array}{c}\text { Patient } \\
\text { no. }\end{array}$ & $\begin{array}{c}\text { MUCb } \\
(\mu \mathrm{g} / \mathrm{L} \times 8 \mathrm{~h})\end{array}$ & $\begin{array}{c}\text { concentration } \\
(\mu \mathrm{g} / \mathrm{L})\end{array}$ & $\begin{array}{c}\text { No. of } \\
\text { peaks }\end{array}$ & $\begin{array}{c}\text { Maximal peak } \\
\text { amplitude } \\
(\mu \mathrm{g} / \mathrm{L})\end{array}$ \\
\hline 1 & 13.2 & 3.4 & 7 & 10.8 \\
3 & 23.3 & 4.0 & 3 & 17.8 \\
4 & 6.2 & 2.3 & 7 & 5.6 \\
6 & 18.0 & 5.7 & 5 & 16.5 \\
9 & 8.7 & 2.3 & 3 & 6.1 \\
11 & 33.0 & 8.2 & 5 & 23.4 \\
13 & 8.0 & 4.5 & 3 & 11.3 \\
15 & 19.6 & 3.8 & 4 & 18.5 \\
16 & 43.9 & 8.8 & 3 & 33.0 \\
17 & 25.1 & 5.7 & 6 & 22.6 \\
18 & 55.0 & 11.2 & 3 & 49.2 \\
\hline
\end{tabular}

* AUCb: Area under the curve over baseline of GH secretion.

The median serum IGFBP-3 concentration was $0.9 \mathrm{SD}$ at 12 mo, 1.7 SD at $24 \mathrm{mo}$, and 1.3 SD at 36 mo after Tx. Serum IGFBP-3 concentration was elevated in three patients and low in one (Fig. 2). One patient with elevated serum IGFBP-3 had a subnormal GFR (EDTA clearance: $48.0 \mathrm{~mL} / \mathrm{min} / 1.73 \mathrm{~m}^{2}$ ). His growth velocity was also markedly reduced and hSDS -5.42 y after Tx. The GFR were normal in the other patients. The low serum IGFBP-3 concentration in one patient was probably caused by reduced liver function due to a vanishing bile duct syndrome diagnosed at the time. Serum IGFBP-3 concentration did not correlate significantly with growth velocity.

Immunosupressive medication. There was no correlation between the weighted average MP dose and growth velocity during the first, second, or third year after Tx. The average MP dose correlated negatively $\left(r_{\mathrm{s}}=-0.47, p<0.005\right)$ with growth velocity when these time periods were pooled together (Fig. 3). However, this correlation was clearly confounded by time elapsed after $\mathrm{Tx}$, and after controlling the effect of time no correlation was found. AZA dose or blood CyA concentration at the follow-up visit did not correlate significantly with growth velocity. Nor was there a correlation between growth velocity and the cumulative dose of CyA.

Endogenous cortisol production. During the first year the basal serum cortisol concentration was low in $11 / 15$ patients, rising to normal later in only two. The stimulated serum cortisol concentration was subnormal in 10/15 patients, and later rose to normal in only one. In two patients endogenous cortisol production was determined only after the first year. One had low basal and stimulated cortisol concentrations (24 mo after Tx), and the other a normal basal cortisol concentration but a subnormal response to stimulation ( 36 mo after Tx).

Basal $\left(r_{\mathrm{s}}=0.44, p<0.05\right)$ and stimulated $\left(r_{\mathrm{s}}=0.53, p<\right.$ $0.005)$ cortisol concentrations correlated positively with growth velocity (Fig. 4). As there was some improvement in cortisol secretion with time, the correlations were weaker after adjustment for the effect of time. In fact, the $p$ value for the correlation between basal cortisol and growth velocity became nonsignificant. There was a weak negative correlation $\left(r_{\mathrm{s}}=-0.33, p<\right.$ 0.05 ) between MP dose and basal cortisol concentration.

\section{DISCUSSION}

Our results and most previous studies demonstrate that, after liver $\mathrm{Tx}$, growth is often retarded. Although many patients are well below the normal range for height at Tx, catch-up growth is not usually observed during the first year, during chronic rejection, or with high dose glucocorticoid treatment $(9,10)$. Without glucocorticoid administration, up to $50 \%$ of all trans- 


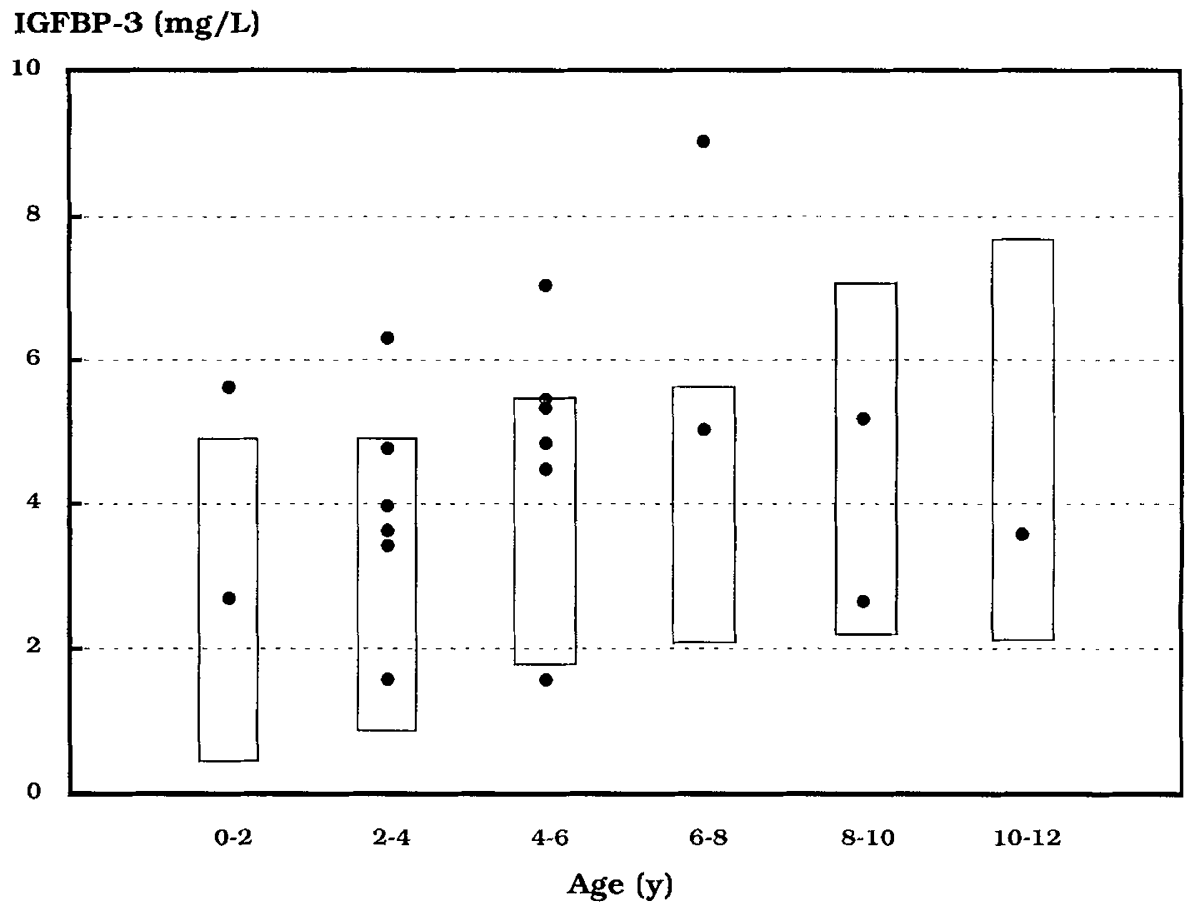

Figure 2. Serum IGFBP-3 concentrations in 13 children after liver Tx. The vertical bars indicate normal ranges ( \pm 2 SD) for each age group, which includes boys and girls.

planted children can be expected to reject their grafts (20). Unfortunately, prolonged glucocorticoid treatment often results in inhibition of linear growth, and the following mechanisms have been proposed (for review, see ref. 21): inhibition of pituitary GH secretion, impaired IGF-I production, induction of IGF-I inhibitors in serum, inhibition of IGF-I action at target tissues, and direct inhibition of skeletal matrix production.

Previously, slightly decreased spontaneous and stimulated GH secretion, suggested to be caused by glucocorticoid administration, have been reported in children with liver transplants (8). Reduced GH secretion has also been reported in 19 renal transplant recipients with severe growth retardation (11). In our patients the average of the mean nocturnal $\mathrm{GH}$ concentration 12 mo after Tx $(5.3 \mu \mathrm{g} / \mathrm{L})$ was very close to values previously reported for children with liver transplants $(5.5 \mu \mathrm{g} / \mathrm{L})$ found to have slightly, but not significantly, lower GH secretion than controls (8). Further, a normal GH response to stimulation was observed in $88 \%$ of our patients.

Although spontaneous GH secretion has been reported to correlate positively with height and growth velocity in healthy children $(14,22)$ and in 19 renal transplant recipients (11), no correlation was found in our patients. Moreover, the peak GH response to stimulation did not correlate with growth velocity. Taken together, our results suggest that reduced GH secretion is not the main factor in the etiology of growth retardation after liver $\mathrm{Tx}$

IGF-I and -II are low molecular weight peptides participating in growth regulation. IGF-I mediates the growth-promoting actions of $\mathrm{GH}$ at least partly (23), correlating positively with height (24), but the physiologic significance of IGF-II in promoting longitudinal growth has not been established. Serum IGF-I levels in children with liver transplants have previously been reported to be normal (8). Our results confirm this observation, for none of our patients had low serum IGF-I levels. Nor was there any correlation between serum IGF-I concentration and growth velocity. However, as IGF-I is believed to stimulate growth partly in an autocrine/paracrine manner, a normal serum concentration does not necessarily exclude a low concentration at tissue level (25). Furthermore, a decrease in the amount of unbound, biologically active IGF-I in serum is also possible.

In serum, IGF-I and -II are bound by at least six IGFBP (26). Circulating IGFBP-3 binds most of the circulating IGF-I, prolongs the half-life of the serum IGF, limits their extravascular transit, and serves as a circulating IGF reservoir. In normal children the serum IGFBP-3 concentration has been reported to correlate positively with height, $\mathrm{GH}$ secretion, and serum IGF concentration $(24,27)$. However, an excess of unsaturated IGFBP inhibit IGF-mediated mitogenic and metabolic events in many tissues and cell lines (28). Increased serum IGFBP-3 levels have also been reported in 19 severely growth-retarded renal transplant recipients with various follow-up times (11).

We found elevated serum IGFBP-3 concentrations in three of our patients, and $40 \%$ of the other patients had values $>1$ $\mathrm{SD}$ above the mean for age. Thus, it can be hypothesized that relatively elevated levels of IGFBP-3 compared with IGF-I may have reduced the amount of unbound, biologically active IGF-I in the circulation, so contributing to the growth failure.

Elevation of the serum IGFBP-3 levels could be caused by MP-induced synthesis of IGFBP-3, which has been shown to occur in liver extracts (29). In addition to renal transplant patients, normal serum IGF-I and elevated serum IGFBP-3 concentrations have been found in children with chronic renal failure, a condition often associated with growth retardation 


\section{Average MP dose $(\mathrm{mg} / \mathrm{kg} / \mathrm{d})$}

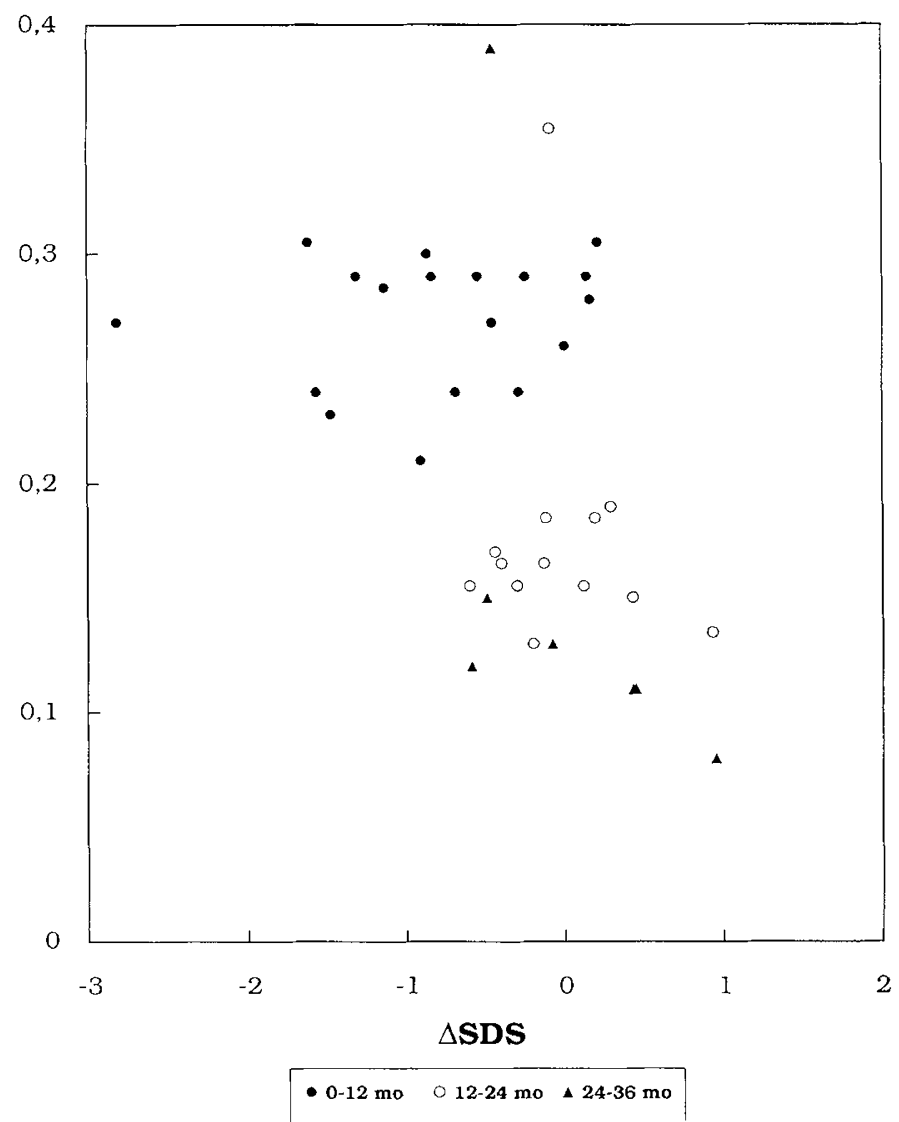

Figure 3. The relation $\left(r_{\mathrm{s}}=-0.47, p<0.005\right)$ of the average MP dose to the change in height SD score ( $\triangle \mathrm{SDS}$ ) during the first, second, and third year after liver $\mathrm{Tx}$ in childhood.
$(11,30,31)$. In these patients the decreased GFR has been suggested to cause accumulation of low molecular weight IGFBP-3 fragments capable of binding free IGF-I in serum (30). All our patients received CyA, a nephrotoxic drug, but only one had a clearly reduced GFR, and also an elevated IGFBP-3 concentration. In our patients $36 \mathrm{mo}$ after $\mathrm{Tx}$, the mean GFR was $119.6 \mathrm{~mL} / \mathrm{min} / 1.73 \mathrm{~m}^{2}$ (32). Thus, rather than reduced renal clearance, the slightly elevated IGFBP-3 levels in our patients presumably resulted from prolonged glucocorticoid treatment, as suggested by Tönschoff et al. (33) in renal transplant recipients.

In most studies performed on renal transplant patients, no correlation has been found between prednisone dose and growth velocity $(34,35)$. This might be due to individual differences in absorption, metabolism, and/or excretion of the drug, making it difficult to predict the magnitude of glucocorticoid-mediated growth inhibition among patients. Accordingly, we found no correlation between the MP dose and growth velocity after Tx. However, there was a positive correlation between growth velocity and endogenous cortisol production, which was the best indicator of growth inhibition in our patients. Thus, at similar doses, corticosteroid sensitivity varies from patient to patient. The ACTH test probably reflects the sensitivity to corticosteroids. Patients with a high sensitivity to exogenous corticosteroids may have a low rate of endogenous corticosteroid production during MP treatment. This may explain why growth velocity is positively correlated with adrenal cortisol production and not negatively correlated with MP dose in our patients.

Reduced adrenal cortisol production may indicate not only the magnitude of the glucocorticoid-mediated growth inhibition, but perhaps also of immunosuppression. Thus, if liver

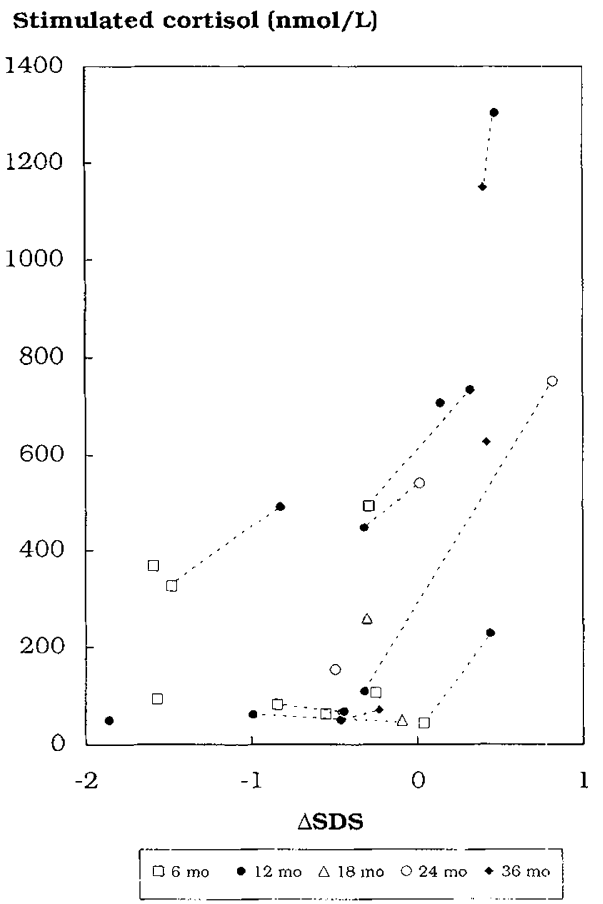

Figure 4. The relation of serum basal $\left(r_{\mathrm{s}}=0.44, p<0.05\right)$ and stimulated $\left(r_{\mathrm{s}}=0.53, p<0.005\right)$ cortisol concentration to the change in height SD score $(\Delta \mathrm{SDS})$ in 17 children 6 to 36 mo after liver Tx. The values for an individual patient are joined with a dashed line. 
function is good but there is a poor response in a rapid ACTH test in a poorly growing child after liver $\mathrm{Tx}$, lowering the glucocorticoid dose could provide for better growth without a risk of rejection. This hypothesis needs to be validated.

The cause of growth retardation after liver $\mathrm{Tx}$ is probably multifactorial. Glucocorticoids seem to play a major role, but the mechanisms remain unclear. Inhibited $\mathrm{GH}$ secretion is probably not the main determinant of growth retardation, and serum IGF-I levels are normal. The amount of free IGF-I in serum is possibly reduced by the relatively high IGFBP-3 levels. Moreover, MP may also inhibit growth plate metabolism directly (21).

In conclusion, after liver Tx 1) the normal pulsatile character of nocturnal GH secretion is sustained, and the $\mathrm{GH}$ response to stimulation is reduced in only a few patients; 2) serum IGF-I concentrations are normal; 3 ) in most patients, serum IGFBP-3 concentrations are elevated or in the upper part of the normal range; and 4) endogenous cortisol production is reduced in most patients and correlates positively with growth velocity.

Recombinant human GH treatment has been used successfully in growth-retarded children with renal transplants (33). Information is not available concerning children with liver transplants, and it is not known whether the factors responsible for growth retardation after liver $\mathrm{Tx}$ can be overcome by administration of $\mathrm{GH}$.

Acknowledgments. The authors thank Mikael Knip, M.D., for the GH assay correlations and Jean Margaret Perttunen, B.Sc. (Hons.), for revising the manuscript.

\section{REFERENCES}

1. Alagille D, Estrada A, Hadchouel M, Gauticr M, Odievre M, Dommegues JP 1987 Syndromic paucity of interlobular bile ducts (Alagille syndrome or arteriohepatic dysplasia): Review of 80 cases. J Pediatr 110: 195-200

2. Kobayashi A, Itabashi F, Ohbe Y 1984 Long-term prognosis in biliary atresia after hepatic portoenterostomy: Analysis of 35 patients who survived beyond 5 years of age. J Pediatr 105:243-246

3. Kaufman SS, Murray ND, Wood RP, Shaw BW, Vanderhoof JA. 1987 Nutritional support for the infant with extrahepatic biliary atresia. J Pediatr 110:679-686

4. Bucuvalas JC, Cutficld W, Horn J, Sperling MA, Heubi JE, Campaigne B, Chernausek SD 1990 Resistance to the growth-promoting and metabolic effects of growth hormone in children with chronic liver disease. J Pediatr 117:397-402

5. Belle SH, Beringer KC, Murphy JB, Detre KM 1992 The Pitt-UNOS liver transplant registry. In: Terasaki PI, Cecka JM (eds) Clinical Transplants 1992. UCLA Tissue Typing Laboratory, Los Angeles, CA, pp 17-32

6. Andrews WS, Wanek E, Fyock B, Gray S, Benser M 1989 Pediatric liver transplantation: A 3-year experience. J Pediatr Surg 24:77-82

7. Urbach AH, Gartner JC, Malatack JJ, Zitelli BJ, Iwatsuki S, Shaw BW, Starzl TE 1987 Linear growth following pediatric liver transplantation. Am J Dis Child 141:547-549

8. Giustina A, Girelli A, Alberti D, Bossoni S, Buzi F, Doga M, Schettino M, Wehrenberg WB 1991 Effects of pyridostigmine on spontaneous and growth hormone-releasing hormone stimulated growth hormone secretion in children on daily gincocorticoid therapy after liver fransplantation. Clin Endocrinol 35:491-498

9. Sarna S, Sipilä I, Jalanko H, Laine J, Holmberg C 1994 Factors affecting growth after pediatric liver transplantation. Transplant Proc 26:161-164

10. Moukarzcl AA, Najm I, Vargas J, McDiarmid SV, Busuttil RW, Ament ME 1990 Prediction of long-term lincar growth following liver iransplantation. Transplant Proc $22: 1558-1559$
11. Hokken-Koelega ACS, Stijnen T, de Muinck Kcizcr-Scrama SMPF, Blun WF, Drop SLS 1993 Levels of growth hormone, insulin-like growth factor-I (IGF-I) and -II, IGF-binding protein- 1 and -3 , and cortisol in prednisone-1reated children with growth retardation after renal transplantation. J Clin Endocrinol Metab 77:932-938

12. Ocllerich M, Raude E, Burdelski M, Schulz M, Schmidt FW, Ringe B, Lamesch P, Pichlmayr R, Raith H, Scheruhn M 1987 Monocthylglycinexylidide formation kinetics: a novel approach to assessment of liver function. J Clin Chem Clin Biochem 25:845-853

13. Tanner JM, Whitehouse RH, Camcron N, Marshall WA, Healy MJR, Goldstein H 1983 Assessment of Skclctal Maturity and Prediction of Adult Height (TW2 Mcthod), 2nd Ed. Academic Press, London

14. Albertsson-Wikland K, Rosberg S 1988 Analyses of 24-hour growth hormone profiles in children: Relation to growth. J Clin Endocrinol Metab 67:493-500

15. Leisti S, Perhecntupa J 1978 Two-hour adrenocorticotropic hormone test: Accuracy in the evaluation of the hypothalamic-piluitary-adrenocortical axis. Pediatr Res $12: 272-278$

16. Clemmons DR, Underwood LE, Chatelain PG, Van Wyk JJ 1983 Libcration of immunoreactive somatomedin-C from its binding proteins by proteolytic enzymes and heparin. J Clin Endocrinol Metab 56:384-389

17. Koistinen H, Seppälä M, Koistinen R 1994 Different forms of insulin-like growth factor-binding protein- 3 detected in scrum and seminal plasma by immunofluorometric assay with monoclonal antibodics. Clin Chem 40:531-536

18. Sorva R, Lankinen S, Tolppanen EM, Perhecntupa J 1990 Variation of growth in height and weight of children. Acta Paediatr Scand 79:498-506

19. Durant R, Linder EW 1981 An evaluation of 5 indexes of relative body weight for use with children. J Am Dict Assoc 78:35-38

20. Reisman L, Lieberman KV, Burrows L, Schanzcr H 1990 Follow-up of cyclosporinetreated pediatric renal allograft recipients after cessation of prednisone. Transplantation 49:76-80

21. Mehls O, Tönschoff B, Kovacs G, Mayer C, Scurck J, Oh J 1993 Interaction between glucocorticoids and growth hormone. Acla Pacdiatr Suppl 388:77-82

22. Hindmarsh P, Smith PJ, Brook CGD, Matthews DR 1987 The relationship between height velocity and growth hormone secretion in short prepubertal children. Clin Endocrinol 27:581-591

23. Blum WF, Ranke MB 1990 Use of insulin-like growth factor-binding protein 3 for the evaluation of growth disorders. Horm Res 33(suppl 4):31-37

24. Blum WF, Albertsson-Wikland K, Rosbere S, Ranke MB 1993 Serum insulin-like growth factor I (IGF-I) and IGF binding protein 3 reflect spontaneous growth hormone secretion. J Clin Endocrinol Metab 76:1610-1616

25. Luo J, Murphy LJ 1989 Dexamethasone inhibits growth hormone induction of insulin-like growth factor-1 (IGF-I) messenger ribonucleic acid (mRNA) in hypophysectomized rats and reduces IGF-I mRNA abundance in the intact rat. Endocrinology 125:165-171

26. Rechler MM, Brown AL 1992 Insulin-like growth factor binding proteins: Gene structure and expression. Growth Regul 2:55-68

27. Hardouin S, Gourmelen M, Noguiez P, Seurin D, Roghani M, Le Bouc Y, Povoa G, Merimec TJ, Hosscnlopp P, Binoux M 1989 Molecular forms of scrum insulin-like growth factor (IGF)-binding proteins in man: Relationships with growth hormone and IGFs and physiological significance. J Clin Endocrinol Metab 69:1291-1301

28. Clemmons DR 1992 IGF binding proteins: regulation of ccllular actions. Growth Regul 2:80-87

29. Binoux M, Lassarre C, Hardouin N 1982 Somatomedin production by rat liver in organ culture. III. Studies on the relcase of insulin-like growth factor and its carrier protein measured by radioligand assays. Effect of growth hormone, insulin and cortisol. Acta Endocrinol 99:422-426

30. Powell DR, Liu F, Baker B, Lce PDK, Bclsha CW, Brewer ED, Hintz R 1993 Characterization of insulin-like growth factor binding protcin-3 in chronic renal failure serum. Pediatr Res 33:136-143

31. Lee PDK, Hintz RL, Sperry JB, Baxtcr RC, Powcll DR 1989 IGF binding proteins in growth-retarded children with chronic renal failurc. Pediatr Res 26:308-315

32. Laine J, Krogerus L, Fyhrquist F, Jalanko H, Rönnholm K, Holmberg C 1994 Renal function and histopathology after liver transplantation in children. J Pediatr 125:863869

33. Tönschoff B, Haffner D, Mehls O, Dietz M, Ruder H, Blum WF, Heinrich U, Stöver B 1993 Efficacy and safety of growth hormone treatment in short children with renal allografts: Three year experience. Kidney In1 44:199-207

34. Rees L, Greene SA, Adlard P, Jones J, Haycock GB, Ridgen SPA, Precee M, Chantler C 1988 Growth and endocrine function after renal transplantation. Arch Dis Child 63:1326-1332

35. Tejani A, Fine R, Alexander S, Harmon W, Stablein D 1993 Factors predictive of sustained growth in children after renal transplantation. J Pediatr 122:397-402 